\title{
Evaluation of eco-design strategies for development of multiple life-cycle products
}

\author{
T.F. Go ${ }^{1}$, D.A. Wahab ${ }^{1,2 *}$ and H. Hishamuddin ${ }^{1,2}$ \\ ${ }^{1}$ Department of Mechanical and Materials Engineering, Faculty of Engineering and \\ Built Environment, Universiti Kebangsaan Malaysia, \\ 43600 UKM Bangi, Selangor, Malaysia \\ ${ }^{2}$ Center for Automotive Research, Faculty of Engineering and Built Environment, \\ Universiti Kebangsaan Malaysia, 43600 UKM Bangi, Selangor, Malaysia, \\ Phone: +603-89216118; Fax: +603-89259659 \\ *Email: dzuraidah@ukm.edu.my
}

\begin{abstract}
Life-cycle thinking in the development of new products has led design engineers to rethink the way they design sustainable products. One of the most viable approaches is designing products for multiple life-cycles. For this purpose, a sustainable design tool that has a broader perspective in providing design guidelines to enhance end-of-life product recovery for multiple life-cycles is necessary. However, there are too many design requirements, some of which are conflicting. Designers are not supported by specific methodologies or tools to evaluate the weightage and importance of the design elements. Therefore, an extensive review of the design requirements of remanufacturable products was conducted in order to identify the design elements for multiple life-cycle products. A modified Analytical Hierarchy Process method was developed based on the design strategies in order to obtain the weightage that indicates the importance of each design element. The proposed approach is capable of refining and setting priorities in strategic decision-making during the design phase of a multiple life-cycle product. Verification of the strategic factors was based on an in-depth interview with an automobile engine remanufacturer. Based on the study, disassemblability and assemblability were found to be the two most important criteria in designing automobile engines for multiple lifecycles.
\end{abstract}

Keywords: Multiple life-cycles; design for X; design guidelines; weightage.

\section{INTRODUCTION}

There has been a shift in developing sustainable products by extending their useful lives through multiple life-cycle [1]. In contrast to single life-cycle products, which are disposed of by the consumer after a single use, multiple life-cycle products are reused by the remanufacturer and consequently by the consumer, as a whole or as a reusable part of a remanufacturable product [2]. A diagrammatic representation of the Single Life-Cycle processes is shown in Figure 1 as an open-loop material flow and the Multiple Life-Cycle (MLC) processes is shown in Figure 2 as a closed-loop material flow. It can be clearly observed from Figure 2 that the 6Rs concept (Reduce, Reuse, Recycle, Remanufacture, Redesign and Recover) plays an important role in enabling multiple product lifecycles[3]. Reuse, Recycle and Remanufacturing do not require first-use materials in the closed-loop material flow, therefore, reducing the need for virgin materials and saving 
resources. Recycling may also involve materials that are processed out of one form and Redesigned into another new product.

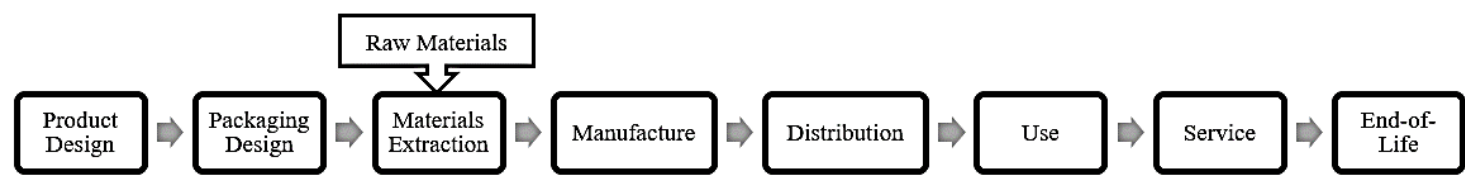

Figure 1. Single life-cycle processes (adapted from [4] )

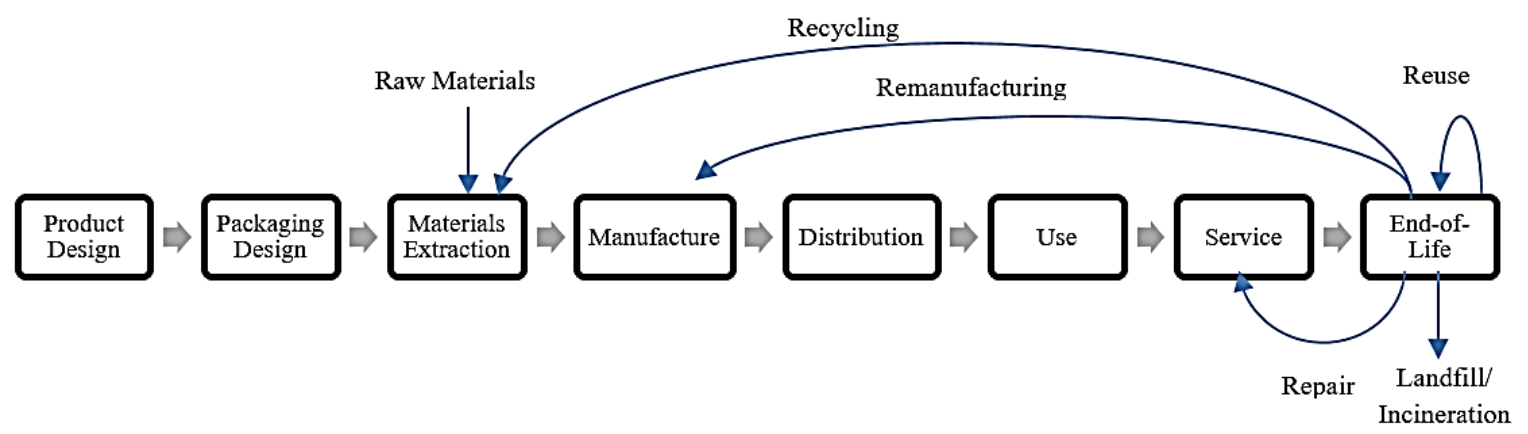

Figure 2. Multiple life-cycles processes [5]

Therefore, creating sustainable value requires product, process and systems level innovations to enable near-perpetual closed-loop material flow across multiple lifecycles[6]. Designing products that are never discarded could be a new concept for a near future trend [7]. However, most traditional design is focused on functionality and cost at the expense of environmental issues [8], and designers lack knowledge and awareness of multiple life-cycle considerations in their work. Therefore, it is imperative for a design engineer to acquire the capability to build components or modules that will support Multiple Life-Cycle Products (MLCP) [9].

\section{End-of-Life Vehicle}

An end-of-life vehicle (ELV) is a specified vehicle that is discarded, or is to be discarded, by its registered owner as waste [10]. ELVs can be categorised as natural or premature. A natural ELV reaches the end of its useful life after an average life span, while a premature ELV reaches the end of its useful life before its average lifespan owing to damage from a heavy accident $[10,11]$. The number of vehicles disposed of annually in the USA is 8-10 million, 14 million in Europe and about 30 million in other parts of the world [12]. The Malaysian Automotive Association [13] pointed out that Malaysia is also facing the same issue as the number of vehicles has increased continuously from 1980, as shown in Table 1. Therefore, the automotive industry is responsible for considerable quantities of waste in the country [14]. Moreover, [15] indicated that automobiles affect the environment through their entire life-cycle, thus recovery strategies for automobiles are becoming important owing to energy and environmental issues. One of the recent trends in automotive design is aimed at improving environmental-friendliness [16]. Furthermore, Malaysia's 2014 National Automotive Policy (NAP) was launched with a vision to enhance the competitive advantage of the local automotive industry and also to develop an environmentally friendly automotive manufacturing ecosystem and outputs [17]. Therefore, industrial application of environmentally conscious design should lead 
to a growing awareness of the need for a more sustainable approach to the current practices in order to solve the problem of the growing amount of waste generated by ELVs. One way to improve the life-cycle utilisation of products is to extend their longevity [18] by allowing products to have more than one life-cycle.

Table 1. Production of vehicles in Malaysia in 2007-2015 [13].

\begin{tabular}{cccc}
\hline Year & Passenger vehicles & Commercial vehicles & Total vehicle \\
\hline $\mathbf{2 0 0 7}$ & 442,885 & 44,291 & 487,176 \\
$\mathbf{2 0 0 8}$ & 497,459 & 50,656 & 548,115 \\
$\mathbf{2 0 0 9}$ & 486,342 & 50,563 & 536,905 \\
$\mathbf{2 0 1 0}$ & 543,594 & 61,562 & 605,156 \\
$\mathbf{2 0 1 1}$ & 535,113 & 65,010 & 600,123 \\
$\mathbf{2 0 1 2}$ & 552,189 & 75,564 & 627,753 \\
$\mathbf{2 0 1 3}$ & 576,657 & 79,136 & 655,793 \\
$\mathbf{2 0 1 4}$ & 588,341 & 78,124 & 666,465 \\
YTD June 2015 & 286,533 & 35,651 & 322,184 \\
\hline
\end{tabular}

Motor Teknologi \& Industri Sdn Bhd (MTI) in Malaysia provides remanufacturing services that extend the life of equipment, engines, vehicles and machinery, enabling them to operate in "as-good-as-new" condition [19] in their second life-cycle. Caterpillar heavy-duty engines can be remanufactured as many as six times, thereby providing seven life-cycles [20]. The advantages of engine remanufacturing include savings in virgin materials leading to a significant profit while providing opportunities for manufacturing energy savings [21]. Even though automotive manufacturers implicitly conduct life-cycle planning and product design from a life-cycle perspective, specific methodologies have not been deployed [20,21] owing to the fact that design and development of an automotive engine involves complicated processes [22]. To acquire the best performance and optimise the engine design in any operating condition, many analytical tools and experimental works are needed to find the optimum structure for the engine design [23].

\section{Design for Multiple Life-Cycles and Design For X}

In this study, a Multiple Life-Cycle Product (MLCP) is defined as a product that has the potential to extend its asset life through secondary or multiple life-cycle usages. Gao [24] developed a methodology to complete the disassembly levelling and assignment decisions in demanufacturing and later implemented them in a demanufacturing module of a MultiLife-Cycle Assessment and Analysis tool. Huang and Tzeng [25] developed a forecast methodology to allow for predictions of the product lifetime and the annual shipment of products during the entire product life-cycle of the multiple generation products. presented a delayed differentiation for the MLCP in order to provide guidance on the evolutionary nature of the push-pull boundary and potential cost savings over full disassembly. Sayin and Canakci [26] conducted a study on the planning of multiplegeneration product lines using dynamic variable state models with data input from similar products. Dunmade [27] proposed design features and service life operations to facilitate MLCP. Previous studies have also indicated that more than $70 \%$ of the product life-cycle cost is determined at the end of the product design stage[28, 29]. Thus, it is imperative for the generation of MLCP to be projected correctly and in a timely manner at this stage in order for an end-of-life (EOL) product to be remanufactured viably. Therefore, a new design approach will be vital for this new design strategy. 
Table 2. The various levels of design for multiple life-cycles (DFX).

\begin{tabular}{|c|c|c|}
\hline & DFX & Objectives \\
\hline DFMLC & $\begin{array}{l}\text { Design for Multiple Life-Cycles } \\
\text { [1] }\end{array}$ & $\begin{array}{l}\text { - To design for longevity } \\
\text { - To design for component recovery } \\
\text { - To design for modularity } \\
\text { - To design for serviceability } \\
\text { - To promote multiple utilisation of } \\
\text { component }\end{array}$ \\
\hline DFE & $\begin{array}{l}\text { Design for Environment } \\
\text { [30] }\end{array}$ & $\begin{array}{l}\text { - To reduce or eliminate environmental } \\
\text { impacts from cradle to grave }\end{array}$ \\
\hline DFMR & $\begin{array}{l}\text { Design for Material Recovery } \\
\text { (Design for Recycling) } \\
\text { [31-33] }\end{array}$ & $\begin{array}{l}\text { - For better materials recovery } \\
\text { - To promote materials that can be recycled } \\
\text { - For easier materials identification }\end{array}$ \\
\hline DFCR & $\begin{array}{l}\text { Design for Component } \\
\text { Recovery (Design for Reuse \& } \\
\text { Design for } \\
\text { Remanufacturing) } \\
\text { [34-37] }\end{array}$ & $\begin{array}{l}\text { - To promote reuse of components } \\
\text { - To ensure reliability of the multiple } \\
\text { utilisation of component is not lower than } \\
\text { the original requirements } \\
\text { - To lead to savings in energy, production } \\
\text { costs and volumes of virgin material in } \\
\text { production }\end{array}$ \\
\hline DFA & $\begin{array}{l}\text { Design for Assembly } \\
{[5,31]}\end{array}$ & $\begin{array}{l}\text { - To minimise the time required to } \\
\text { reassemble the product } \\
\text { - To prevent damage during part insertion }\end{array}$ \\
\hline DFD & $\begin{array}{l}\text { Design for Disassembly } \\
{[5,36,37]}\end{array}$ & $\begin{array}{l}\text { - To minimise the time required to } \\
\text { disassemble the product } \\
\text { - For a complete disassembly }\end{array}$ \\
\hline DFU & Design for Upgrade [38] & $\begin{array}{l}\text { - For upgrades particularly relevant to } \\
\text { remanufacturing } \\
\text { - For upgrading product functions to meet } \\
\text { customers' requirements from time to time }\end{array}$ \\
\hline DFR & Design for Durability [39] & $\begin{array}{l}\text { - To make sure components are robust } \\
\text { enough to reuse }\end{array}$ \\
\hline DFMo & $\begin{array}{l}\text { Design for Modularity } \\
{[26,40,41]}\end{array}$ & $\begin{array}{l}\text { - For ease of upgrading } \\
\text { - For ease of serviceability } \\
\text { - For ease of disassembly }\end{array}$ \\
\hline DFMa & $\begin{array}{l}\text { Design for Maintainability } \\
\text { [41] }\end{array}$ & $\begin{array}{l}\text { - For enhanced serviceability } \\
\text { - For ease of repairs and to provide longer life } \\
\text { - To maintain quality of the product } \\
\text { - To minimise disposal of non-working } \\
\text { products }\end{array}$ \\
\hline
\end{tabular}

However, the existing product design guidelines comprising eco-design requirements are still fragmented and not integrated to support the generation of a product for multiple life-cycles. It is now necessary to work at the interfaces of the various disciplines of Design for X (DFX) guidelines in order to address complex issues that are brought about by the requirements of multiple life-cycles. Table 2 summarises the various DFX objectives in order to promote Design for Multiple Life-Cycles (DFMLC). According to [42], product and process design to facilitate remanufacturing are the challenges in remanufacturing research. Most of the developed tools require too much technical data and are either too complex to be used in the early design stage, or by the 
time the product specification has been defined, it is too late to make substantial changes to the design [42]. Therefore, in order to recover value from an ELV, this study provides a framework for evaluating design strategies during the design of an automotive component with the multiple life-cycle concept. The objective of this paper is to discuss and analyse the design elements that enhance the ability of a product to undergo more than one life-cycle. Priority determination of MLCP design elements based on proactive strategies is also presented and discussed.

\section{MATERIALS AND METHODS}

\section{The Proposed DFMLC Framework}

A research framework for the development of an MLC design tool is presented in Figure 3. The framework enables a designer to identify important design elements and compute the priority of these design elements during the development of a multiple lifecycles product. DFMLC is recommended to be implemented as early as the conceptual design stage in which design decisions are made.

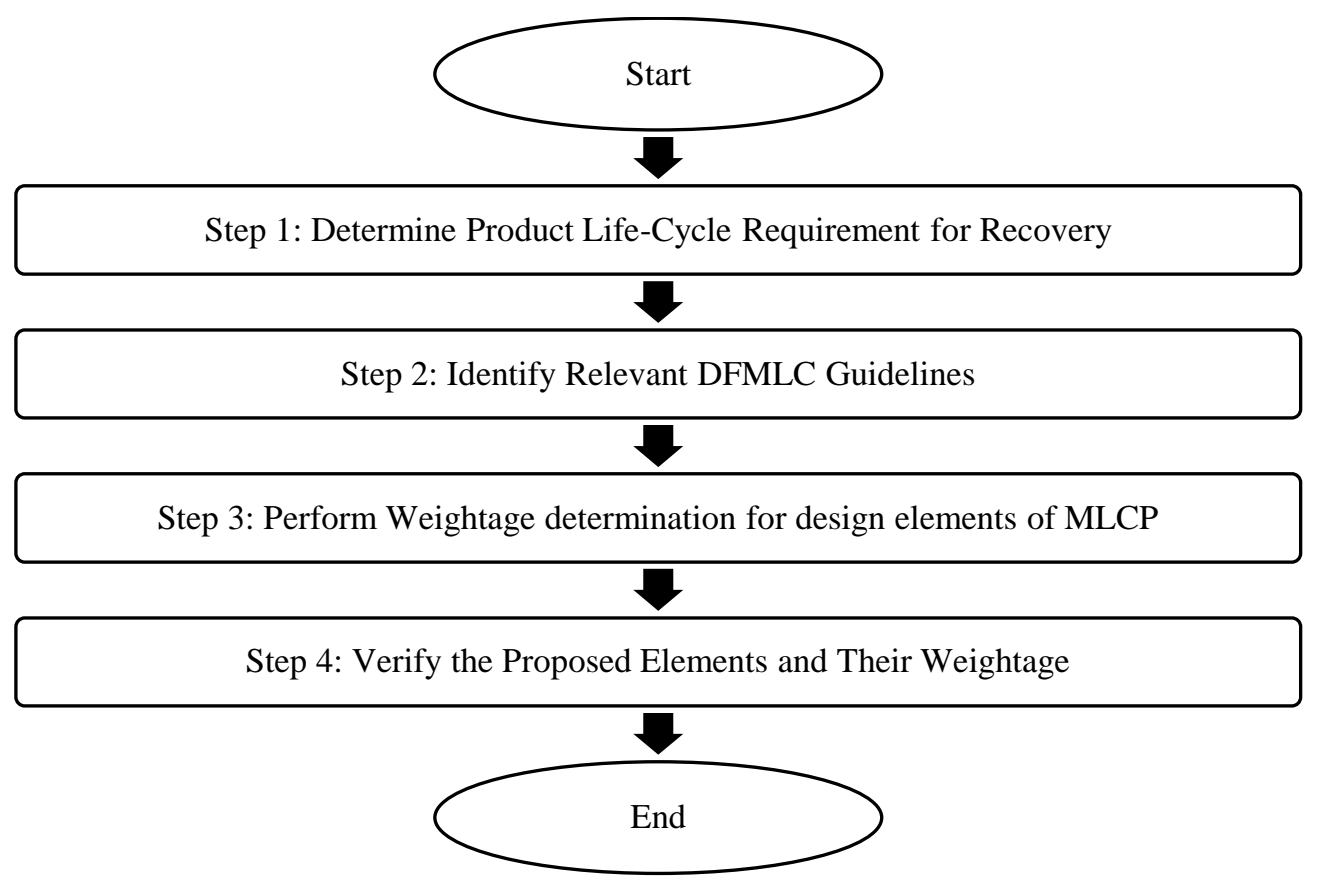

Figure 3. The proposed DFMLC framework.

\section{Elements of the Framework}

The proposed framework consists of the following steps:

Step 1

A comprehensive study of the requirements for remanufacturable products was conducted based on 25 publications, as shown in Table 2 . The study was aimed at identifying the design elements for a multiple life-cycle product. The 25 publications were found in several databases, such as Elsevier, Springer, ISAHP and ASME, during the period of 2007-2016. The MLCP requirements were compiled as shown in Table 3. The data presented in Table 4 was analysed using IBM SPSS Statistics 23 to compute their ' $t$ 
Statistic' from the one-sample t-test. The test statistic of the one-sample t test is calculated by dividing the mean difference by the standard error mean.

Table 3. A Compilation of Studies Related to Remanufacturing in 2007-2016.

\begin{tabular}{llll}
\hline No & Author(s) & Year & Database \\
\hline $\mathbf{1}$ & {$[42]$} & 2016 & Springer \\
$\mathbf{2}$ & {$[43]$} & 2016 & Elsevier (SCOPUS) \\
$\mathbf{3}$ & {$[44]$} & 2015 & Elsevier (SCOPUS) \\
$\mathbf{4}$ & {$[45]$} & 2015 & Springer \\
$\mathbf{5}$ & {$[46]$} & 2015 & Elsevier (SCOPUS) \\
$\mathbf{6}$ & {$[47]$} & 2015 & Springer \\
$\mathbf{7}$ & {$[1]$} & 2015 & Elsevier (SCOPUS) \\
$\mathbf{8}$ & {$[48]$} & 2015 & Springer \\
$\mathbf{9}$ & {$[49]$} & 2015 & Elsevier (SCOPUS) \\
$\mathbf{1 0}$ & {$[50]$} & 2015 & Elsevier (SCOPUS) \\
$\mathbf{1 1}$ & {$[51]$} & 2014 & Elsevier (SCOPUS) \\
$\mathbf{1 2}$ & {$[52]$} & 2014 & Elsevier (SCOPUS) \\
$\mathbf{1 3}$ & {$[53]$} & 2013 & ISAHP \\
$\mathbf{1 4}$ & {$[54]$} & 2013 & Elsevier (SCOPUS) \\
$\mathbf{1 5}$ & {$[26]$} & 2013 & IJERA \\
$\mathbf{1 6}$ & {$[55]$} & 2012 & Intech \\
$\mathbf{1 7}$ & {$[56]$} & 2011 & Elsevier (SCOPUS) \\
$\mathbf{1 8}$ & {$[57]$} & 2011 & Springer \\
$\mathbf{1 9}$ & {$[28]$} & 2010 & Elsevier \\
$\mathbf{2 0}$ & {$[58]$} & 2010 & Taylor \& Francis (SCOPUS) \\
$\mathbf{2 1}$ & {$[59]$} & 2010 & ASME \\
$\mathbf{2 2}$ & {$[60]$} & 2008 & Inderscience (SCOPUS) \\
$\mathbf{2 3}$ & {$[61]$} & 2007 & Elsevier (SCOPUS) \\
$\mathbf{2 4}$ & {$[62]$} & 2007 & CRR \\
$\mathbf{2 5}$ & {$[63]$} & 2007 & Inderscience (SCOPUS) \\
\hline
\end{tabular}

Step 2

DFMLC design guidelines are proposed via a critical review of literature related to DFXs. The relevant guidelines are categorised as 'provision', 'maximisation', 'minimisation', 'avoidance' and 'location'.

Step 3

A weightage determinant method for MLCP design elements was developed based on the Analytical Hierarchy Process (AHP). AHP was selected as a weightage determination tool as it is a quantitative method for decision formulation and analysis that can determine the weights of all assessment factors [64]. It has been used by many researchers in applications related to design problems [65]. AHP was invented by Prof. Saaty in the late 1970s in the USA [66]. Zhang, Ouzrout [66] summarised AHP into four elements:

i. Structuring multiple choice criteria into a hierarchy,

ii. Assessing the relative importance of these criteria,

iii. Comparing alternatives for each criterion, and 
iv. Determining an overall ranking of the alternatives.

In this study, a four-level hierarchy structure for designing MLC products was proposed, each level representing the main goal, design criteria, DFX and design elements respectively.

Table 4. Mapping between design elements with References.

\begin{tabular}{|c|c|c|c|c|c|c|c|c|c|c|c|}
\hline No & & Author(s) & Year & 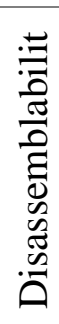 & 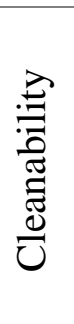 & 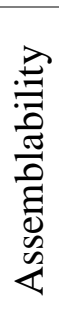 & 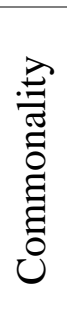 & 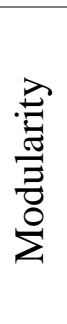 & 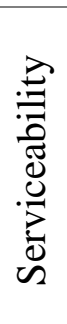 & 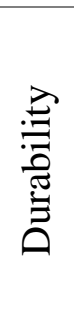 & 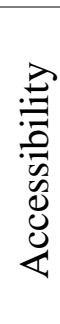 \\
\hline 1 & [42] & & 2016 & 1 & 1 & 1 & 1 & 0 & 1 & 1 & 1 \\
\hline 2 & [43] & & 2016 & 1 & 1 & 1 & 1 & 1 & 0 & 1 & 0 \\
\hline 3 & [44] & & 2015 & 1 & 1 & 1 & 1 & 1 & 1 & 0 & 0 \\
\hline 4 & [45] & & 2015 & 1 & 1 & 1 & 1 & 0 & 0 & 1 & 0 \\
\hline 5 & [46] & & 2015 & 1 & 1 & 1 & 1 & 0 & 0 & 1 & 0 \\
\hline 6 & [47] & & 2015 & 1 & 1 & 1 & 0 & 0 & 0 & 0 & 0 \\
\hline 7 & [1] & & 2015 & 1 & 1 & 1 & 1 & 1 & 1 & 1 & 0 \\
\hline 8 & [48] & & 2015 & 1 & 1 & 1 & 0 & 0 & 0 & 0 & 0 \\
\hline 9 & [49] & & 2015 & 1 & 1 & 1 & 1 & 0 & 0 & 1 & 0 \\
\hline 10 & [50] & & 2015 & 1 & 1 & 1 & 1 & 0 & 1 & 0 & 0 \\
\hline 11 & [51] & & 2014 & 1 & 1 & 1 & 0 & 0 & 0 & 1 & 0 \\
\hline 12 & [52] & & 2014 & 1 & 1 & 1 & 0 & 0 & 0 & 0 & 1 \\
\hline 13 & [67] & & 2013 & 1 & 1 & 1 & 1 & 0 & 0 & 0 & 0 \\
\hline 14 & [54] & & 2013 & 1 & 1 & 1 & 0 & 0 & 1 & 1 & 1 \\
\hline 15 & [26] & & 2013 & 1 & 1 & 1 & 1 & 1 & 1 & 1 & 1 \\
\hline 16 & [55] & & 2012 & 1 & 0 & 1 & 1 & 1 & 0 & 1 & 1 \\
\hline 17 & [56] & & 2011 & 1 & 1 & 1 & 1 & 1 & 1 & 1 & 1 \\
\hline 18 & [57] & & 2011 & 1 & 1 & 1 & 0 & 1 & 0 & 1 & 0 \\
\hline 19 & [68] & & 2010 & 1 & 1 & 1 & 0 & 0 & 1 & 1 & 0 \\
\hline 20 & [58] & & 2010 & 1 & 1 & 1 & 1 & 0 & 1 & 1 & 1 \\
\hline 21 & [59] & & 2010 & 1 & 0 & 1 & 0 & 1 & 0 & 0 & 0 \\
\hline 22 & [60] & & 2008 & 1 & 1 & 1 & 0 & 1 & 1 & 1 & 1 \\
\hline 23 & [8] & & 2007 & 1 & 1 & 1 & 1 & 1 & 1 & 1 & 0 \\
\hline 24 & [62] & & 2007 & 1 & 1 & 1 & 1 & 0 & 1 & 1 & 0 \\
\hline 25 & [63] & & 2007 & 1 & 1 & 1 & 0 & 0 & 0 & 1 & 0 \\
\hline
\end{tabular}

Step 4

In order to verify the proposed weightage, an in-depth interview with a Malaysian automotive remanufacturer was conducted. There are essentially three different types of remanufacturing company. The first is the Original Equipment Manufacturer (OEM), which remanufactures its own products. The second type is the subcontractor company, which remanufactures products made by other companies (usually the OEMs). Lastly, the Independent Remanufacturer (IR), which remanufactures products without much contact with the OEMs. They also have to buy or collect core components for their remanufacturing process. For the purpose of this study, the interview was conducted with 
a subcontractor engine remanufacturer. The interview was aimed at collecting information to verify the design elements for MLCP and their weightages.

\section{RESULTS AND DISCUSSION}

Products can achieve multiple life-cycles through reuse, remanufacturing or recycling in order to prevent them from becoming waste, that is, by diverting them into another economically viable useful life. It applies mainly to durable products that are placed into service for some period of time and then retired or discarded. There are several automotive components that have potential for multiple life-cycles, such as clutches, brake shoes, engine block, starters, alternators, water pumps and carburettors [37, 69]. Besides that, the remanufacturing of automotive products is an effective strategy to promote sustainability in the automotive industry because, compared to new products, remanufactured products only cost $50 \%$ of the cost for new products, utilise $60 \%$ of energy and 70\% [70], Therefore, an engine was used as a case example in this study. As there are too many design requirements and some of the requirements are conflicting [56], the design requirements have been analysed from a review of 25 publications as shown in Table 3. Table 5 presents the 't statistic' of the design elements that are summarised. Since disassemblability and assemblability have been mentioned in all 25 publications, the standard deviations of these two design elements are equal to 0 , hence their "t statistic" cannot be calculated. These two elements are significant in supporting ease of remanufacturing. The order of importance of the design elements is summarised in Table 8 .

Table 5. 'T-test values' of the design elements.

\begin{tabular}{ll}
\hline Design Elements & $\mathrm{t}$ Statistic \\
\hline Cleanability & 16.613 \\
Commonality & 6.000 \\
Modularity & 4.707 \\
Serviceability & 7.856 \\
Durability & 3.361 \\
Accessibility & 3.361 \\
\hline
\end{tabular}

The critical review of design guidelines from DFX provides directional criteria on designing for multiple generation life-cycles. There are still a number of problems and issues that the guidelines do not sufficiently address, such as conflicts with other design interests, subjectivity and guidelines customisation [56]. Therefore, the relevant guidelines have been categorised into five groups, as mentioned in the section titled "The Elements in Framework". Table 6 provides some examples of the design guidelines; for full details of the design guidelines, please refer to [1].

Figures 4 and 5 represent the AHP hierarchy for a remanufacturable engine from a critical literature review and an interview with a remanufacturer, respectively. The design strategies of remanufacturable automobile engines described in [58] were referred to in which from the House of Quality (HOQ), 41 design strategies were used in were the design of automobile engines for remanufacture. The mapping between the 41 design strategies and proposed design elements in order to determine the pair-wise comparison for AHP is shown in Table 7. Then, the weightage of the design elements were determined by using AHP, as shown in Figure 4. 
Table 6. Examples of design guidelines according to category.

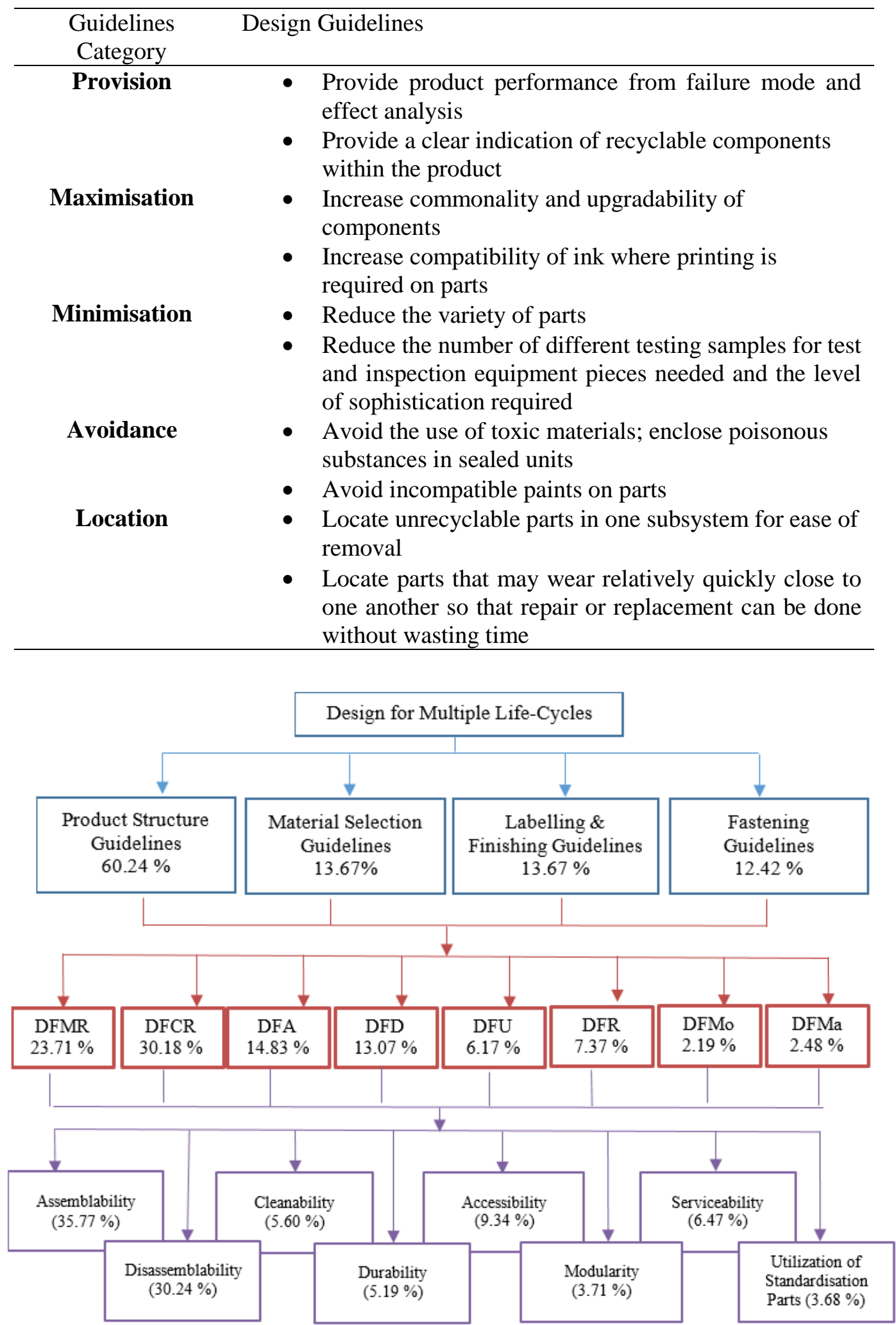

Figure 4. AHP hierarchy for remanufacturable engine generated from HOQ from [58]. 
Table 7. Example of mapping between the design strategies [60] and proposed design elements.

\begin{tabular}{|c|c|c|c|c|c|c|c|c|c|}
\hline No & Design Elements & 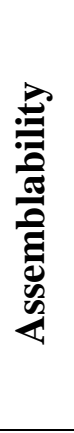 & 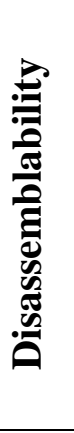 & 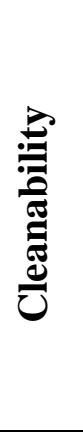 & 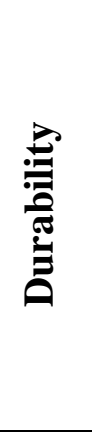 & 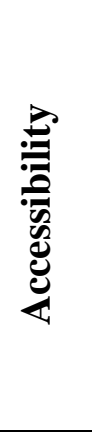 & 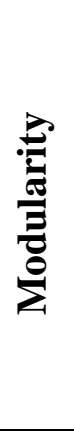 & 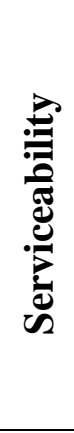 & 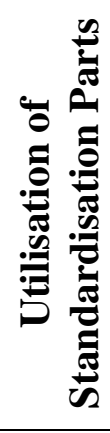 \\
\hline DS 1 & $\begin{array}{l}\text { Accessing the test points should } \\
\text { be easy }\end{array}$ & 1 & 1 & 0 & 0 & 1 & 0 & 1 & 1 \\
\hline DS 2 & $\begin{array}{l}\text { Determining the test points } \\
\text { should be easy }\end{array}$ & 1 & 1 & 0 & 0 & 1 & 0 & 1 & 0 \\
\hline DS 3 & $\begin{array}{l}\text { Not to contact with harmful } \\
\text { materials while testing }\end{array}$ & 1 & 1 & 0 & 1 & 1 & 0 & 1 & 0 \\
\hline DS 4 & $\begin{array}{l}\text { Determining the outworn parts } \\
\text { and the conditions of the parts } \\
\text { should be easy }\end{array}$ & 1 & 1 & 0 & 1 & 1 & 0 & 1 & 0 \\
\hline DS 5 & $\begin{array}{l}\text { Accessing the parts to be cleaned } \\
\text { should be easy }\end{array}$ & 1 & 1 & 1 & 0 & 1 & 0 & 1 & 1 \\
\hline DS 6 & $\begin{array}{l}\text { Parts should not get and keep } \\
\text { dirty }\end{array}$ & 1 & 1 & 1 & 0 & 0 & 0 & 0 & 0 \\
\hline DS 7 & $\begin{array}{l}\text { The surfaces to be cleaned } \\
\text { should be smooth }\end{array}$ & 1 & 1 & 1 & 0 & 0 & 0 & 0 & 0 \\
\hline DS 8 & $\begin{array}{l}\text { The surface should not be } \\
\text { damaged during cleaning }\end{array}$ & 1 & 1 & 1 & 0 & 0 & 0 & 0 & 0 \\
\hline DS 9 & $\begin{array}{l}\text { Residue from cleaning should } \\
\text { not be collected on parts }\end{array}$ & 1 & 1 & 1 & 0 & 0 & 0 & 0 & 0 \\
\hline DS 10 & $\begin{array}{l}\text { The marks on the parts should be } \\
\text { durable for cleaning }\end{array}$ & 1 & 1 & 1 & 0 & 1 & 0 & 0 & 0 \\
\hline DS 11 & $\begin{array}{l}\text { The number of the parts should } \\
\text { be low }\end{array}$ & 1 & 1 & 0 & 0 & 1 & 1 & 1 & 1 \\
\hline
\end{tabular}

As mentioned in the section entitled "Elements of the Framework", an in-depth interview with a subcontractor for engine remanufacturing was conducted. Based on the interview, the weightage of the design elements were determined, as shown in Figure 6. According to [71], ease of access, ease of identification, wear resistance and ease of handling are the most important properties for the design of remanufacturable products. A comparison of the order of importance of design elements from the three studies was carried out and is summarised in Table 8. It can be observed that disassembly and assembly are the two most critical requirements in the design of multiple life-cycle products. Both design criteria are strongly related to the properties of 'ease of access' and 'ease of handling', as suggested by research in [71]. 


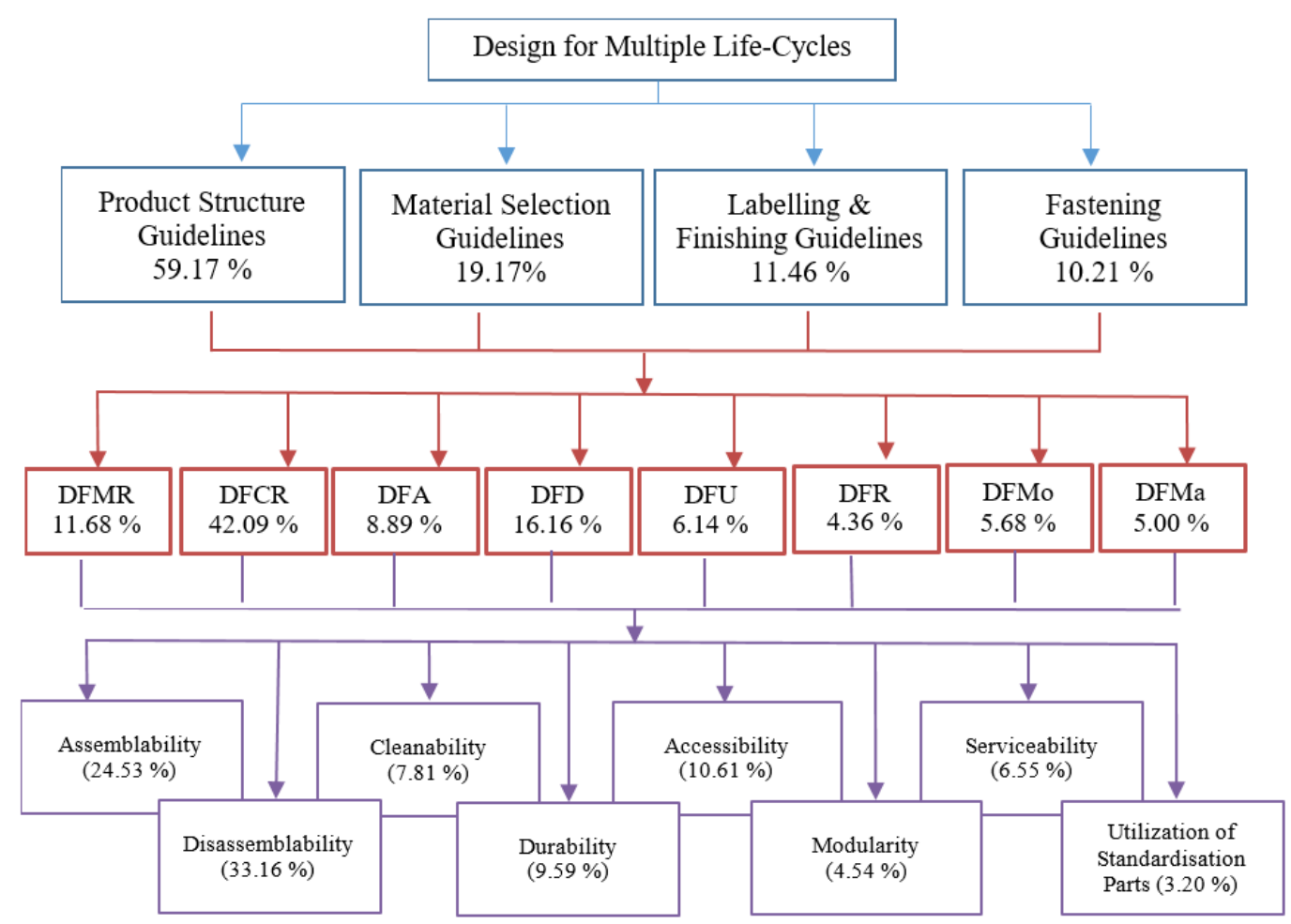

Figure 5. AHP hierarchy for remanufacturable engines based on interview.

Table 8. A comparison of the order of importance of design elements obtained from literature review and in-depth interview.

\begin{tabular}{llccc}
\hline No & Design Elements & $\begin{array}{l}\text { Review of 25 } \\
\text { Related Papers }\end{array}$ & Case study on [58] & $\begin{array}{c}\text { In-depth } \\
\text { Interview }\end{array}$ \\
\hline 1 & Disassemblability & 1,2 & 2 & 1 \\
2 & Cleanability & 3 & 4 & 5 \\
3 & Assemblability & 1,2 & 1 & 2 \\
4 & Commonality & 5 & 8 & 8 \\
5 & Modularity & 6 & 7 & 7 \\
6 & Serviceability & 4 & 6 & 6 \\
7 & Durability & 7,8 & 5 & 4 \\
8 & Accessibility & 7,8 & 3 & 3 \\
\hline
\end{tabular}

\section{CONCLUSIONS}

This paper has introduced a comprehensive framework for determining and evaluating design elements in the development of multiple life-cycle products, using an engine block as a case example. For this purpose, the AHP method was deployed, and the weightage for each of the design elements were established. Results from the study can be applied in design evaluation techniques, such as the Weighted Decision Matrix, and assist designers in making effective decisions on design concepts. This study has proposed a methodology on DFMLC that is capable of contributing significantly towards sustainable development as it retains non-renewable resources in circulation during the multiple 
lifetimes of the products. The proposed method can be implemented as a decision-making tool that will guide designers in the development of environmentally responsible automotive components.

\section{ACKNOWLEDGEMENTS}

The authors would like to extend their greatest appreciation to the Ministry of Education, Malaysia for sponsoring this research under the FRGS grant - FRGS/2/2013/ TK01/ UKM/ 01/1 and Mr Wan Safwan bin Mohd Aris from Motor Teknologi \& Industri Sdn Bhd (MTI) for sharing knowledge and participating in this study.

\section{REFERENCES}

[1] Go T, Wahab DA, Hishamuddin H. Multiple generation life-cycles for product sustainability: the way forward. Journal of Cleaner Production. 2015;95:16-29.

[2] Tsiliyannis C. End-of-life flows of multiple cycle consumer products. Waste management. 2011;31:2302-18.

[3] Jawahir I, Bradley R. Technological elements of circular economy and the principles of 6R-based closed-loop material flow in sustainable manufacturing. Procedia CIRP. 2016;40:103-8.

[4] Bras B. Incorporating environmental issues in product design and realization. Industry and environment. 1997;20:7-13.

[5] Kutz M. Environmentally conscious mechanical design: John Wiley \& Sons; 2007.

[6] Jawahir I, Badurdeen F, Rouch K. Innovation in sustainable manufacturing education: Universitätsverlag der TU Berlin; 2015.

[7] Zwolinski P, Brissaud D. Designing products that are never discarded. Innovation in life cycle engineering and sustainable development: Springer; 2006. p. 225-44.

[8] Ijomah WL, McMahon CA, Hammond GP, Newman ST. Development of design for remanufacturing guidelines to support sustainable manufacturing. Robotics and Computer-Integrated Manufacturing. 2007;23:712-9.

[9] Abbey JD, Guide VDR, Souza GC. Delayed differentiation for multiple lifecycle products. Production and Operations Management. 2013;22:588-602.

[10] Go T, Wahab DA, Rahman MA, Ramli R, Azhari CH. Disassemblability of endof-life vehicle: a critical review of evaluation methods. Journal of Cleaner Production. 2011;19:1536-46.

[11] Saman MZM, Blount G. The DFEL value methodology: a tool for design-forenvironment in automotive industry. Jurnal Mekanikal. 2008;27:23-41.

[12] Blischke WR, Murthy DP. Case studies in reliability and maintenance: John Wiley \& Sons; 2003.

[13] Association MA. Summary of sales and production data. 2012.

[14] Jaichandar S, Annamalai K. Jatropha oil methyl ester as diesel engine fuel-an experimental investigation. International Journal of Automotive and Mechanical Engineering. 2016;13:3248-61.

[15] Mok H, Kim H, Moon K. Disassemblability of mechanical parts in automobile for recycling. Computers \& Industrial Engineering. 1997;33:621-4.

[16] Salwani MS, Sahari B, Ali A, Nuraini A. The effect of automotive side member filling on car frontal impact performance. Journal of Mechanical Engineering and Sciences. 2014;6:873-80. 
[17] MAI (Malaysia Automotive Institute). Malaysia Automotive Roadmap Highlights26 January 2015.

[18] Fiksel J. Design for environment: a guide to sustainable product development: McGraw Hill Professional; 2009.

[19] Cusumano MA. The Japanese automobile industry: Technology and management at Nissan and Toyota: Harvard University Press; 1985.

[20] Umeda Y, Takata S, Kimura F, Tomiyama T, Sutherland JW, Kara S, et al. Toward integrated product and process life cycle planning-An environmental perspective. CIRP Annals-Manufacturing Technology. 2012;61:681-702.

[21] CAT® reman products. 5 December 2015.

[22] Shamsudeen A, Abdullah S, Ariffin A, Rasani M, Ali Y. Design and simulation of a cylinder head structure for a compressed natural gas direct injection engine. International Journal of Automotive and Mechanical Engineering. 2014;9:16209.

[23] Lee C-C, Chiang K-N, Chen W-K, Chen R-S. Design and analysis of gasket sealing of cylinder head under engine operation conditions. Finite Elements in Analysis and Design. 2005;41:1160-74.

[24] Gao M. Optimal and intelligent decision making in sustainable development of electronic products: New Jersey Institute of Technology; 2003.

[25] Huang C-Y, Tzeng G-H. Multiple generation product life cycle predictions using a novel two-stage fuzzy piecewise regression analysis method. Technological Forecasting and Social Change. 2008;75:12-31.

[26] Sayin C, Canakci M. Effects of injection timing on the engine performance and exhaust emissions of a dual-fuel diesel engine. Energy Conversion and Management. 2009;50:203-13.

[27] Dunmade I. Design for Multi-Lifecycle: A Sustainability Design Concept.

[28] Sayin C. The impact of varying spark timing at different octane numbers on the performance and emission characteristics in a gasoline engine. Fuel. 2012;97:85661.

[29] Mohamad TI, How HG. Part-load performance and emissions of a spark ignition engine fueled with RON95 and RON97 gasoline: Technical viewpoint on Malaysia's fuel price debate. Energy Conversion and Management. 2014;88:92835.

[30] Celik MB. Experimental determination of suitable ethanol-gasoline blend rate at high compression ratio for gasoline engine. Applied Thermal Engineering. 2008;28:396-404.

[31] $\mathrm{Li} \mathrm{T}, \mathrm{Wu} \mathrm{D}, \mathrm{Xu} \mathrm{M}$. Thermodynamic analysis of EGR effects on the first and second law efficiencies of a boosted spark-ignited direct-injection gasoline engine. Energy Conversion and Management. 2013;70:130-8.

[32] Heywood J. Internal combustion engine fundamentals: McGraw-Hill Education; 1988.

[33] Esterhuyse N, Yates A. A Study to Assess the Effect of Octane on Vehicle Emissions. SAE Technical Paper; 2002.

[34] Sayin C, Ertunc HM, Hosoz M, Kilicaslan I, Canakci M. Performance and exhaust emissions of a gasoline engine using artificial neural network. Applied Thermal Engineering. 2007;27:46-54.

[35] Kaebernick H, Kara S. Reuse and recycling technologies. Environmentally Conscious Mechanical Design: Wiley Hoboken. 2007;249-82. 
[36] Gerrard J, Kandlikar M. Is European end-of-life vehicle legislation living up to expectations? Assessing the impact of the ELV Directive on 'green'innovation and vehicle recovery. Journal of Cleaner Production. 2007;15:17-27.

[37] Amelia L, Wahab DA, Haron CC, Muhamad N, Azhari CH. Initiating automotive component reuse in Malaysia. Journal of Cleaner Production. 2009;17:1572-9.

[38] Pialot O, Millet D, Tchertchian N. How to explore scenarios of multiple upgrade cycles for sustainable product innovation: the "Upgrade Cycle Explorer" tool. Journal of Cleaner Production. 2012;22:19-31.

[39] Gertsakis J, Morelli N, Lewis H, Sweatman A, Grant T. Design+ Environment: a global guide to designing greener goods: Greenleaf Publishing Limited; 2001.

[40] Östlin J, Sundin E, Björkman M. Product life-cycle implications for remanufacturing strategies. Journal of cleaner production. 2009;17:999-1009.

[41] Abdullah AB, Yusoff M, Mohd Ripin Z. Integration Of Design For Modularity And Design For Assembly To Enhance Product Maintainability. 2006.

[42] Matsumoto M, Yang S, Martinsen K, Kainuma Y. Trends and research challenges in remanufacturing. International Journal of Precision Engineering and Manufacturing-Green Technology. 2016;3:129-42.

[43] Bauer T, Mandil G, Naveaux É, Zwolinski P. Lifespan Extension for Environmental Benefits: A new Concept of Products with Several Distinct Usage Phases. Procedia CIRP. 2016;47:430-5.

[44] Yang S, Ngiam H, Ong S, Nee A. The impact of automotive product remanufacturing on environmental performance. Procedia CIRP. 2015;29:774-9.

[45] Wei S, Tang O, Sundin E. Core (product) Acquisition Management for remanufacturing: a review. Journal of Remanufacturing. 2015;5:1-4.

[46] Steinhilper R, Weiland F. Exploring New Horizons for Remanufacturing an Upto-date Overview of Industries, Products and Technologies. Procedia CIRP. 2015;29:769-73.

[47] Priyono A, Ijomah WL, Bititci US. Strategic operations framework for disassembly in remanufacturing. Journal of Remanufacturing. 2015;5:1-11.

[48] Karvonen I, Jansson K, Tonteri H, Vatanen S, Uoti M. Enhancing remanufacturing-studying networks and sustainability to support Finnish industry. Journal of Remanufacturing. 2015;5:5.

[49] Kurilova-Palisaitiene J, Sundin E. Toward pull remanufacturing: A case study on material and information flow uncertainties at a german engine remanufacturer. Procedia CIRP. 2015;26:270-5.

[50] Kurilova-Palisaitiene J, Lindkvist L, Sundin E. Towards facilitating circular product life-cycle information flow via remanufacturing. Procedia CIRP. 2015;29:780-5.

[51] Goodall P, Rosamond E, Harding J. A review of the state of the art in tools and techniques used to evaluate remanufacturing feasibility. Journal of Cleaner Production. 2014;81:1-15.

[52] Fang H, Ong S, Nee A. Product remanufacturability assessment based on design information. Procedia CIRP. 2014;15:195-200.

[53] Shumon MRH, Ahmed S, Ahmed S. Fuzzy analytical hierarchy process extent analysis for selection of end of life electronic products collection system in a reverse supply chain. Proceedings of the Institution of Mechanical Engineers, Part B: Journal of Engineering Manufacture. 2016;230:157-68. 
[54] Hatcher GD, Ijomah W, Windmill J. Integrating design for remanufacture into the design process: the operational factors. Journal of Cleaner Production. 2013;39:200-8.

[55] Gallo M, Romano E, Santillo LC. A Perspective on Remanufacturing Business: Issues and Opportunities: INTECH Open Access Publisher; 2012.

[56] Hatcher G, Ijomah W, Windmill J. Design for remanufacture: a literature review and future research needs. Journal of Cleaner Production. 2011;19:2004-14.

[57] Matsumoto M, Umeda Y. An analysis of remanufacturing practices in Japan. Journal of Remanufacturing. 2011;1:2.

[58] Yüksel H. Design of automobile engines for remanufacture with quality function deployment. International Journal of Sustainable Engineering. 2010;3:170-80.

[59] Zhao Y, Pandey V, Kim H, Thurston D. Varying lifecycle lengths within a product take-back portfolio. Journal of Mechanical Design. 2010;132:091012.

[60] Gray C, Charter R. Remanufacturing and product design. International Journal of Product Development; 2017.

[61] Hoepke B, Jannsen S, Kasseris E, Cheng WK. EGR effects on boosted SI engine operation and knock integral correlation. SAE International Journal of Engines. 2012;5:547-59.

[62] Parker D, Butler P. An introduction to remanufacturing. Centre for Remanufacturing \& Reuse, Aylesbury, UK, 2012.

[63] Thurston DL, De La Torre JP. Leasing and extended producer responsibility for personal computer component reuse. International Journal of Environment and Pollution. 2007;29:104-26.

[64] Wanga J, Yaob C, Zhang Z. A fuzzy-AHP comprehensive evaluation method for optimization design of machine tool. International Conference on Mechanic Automation and Control Engineering. 2010; 2652-6.

[65] Armacost RL, Componation PJ, Mullens MA, Swart WW. An AHP framework for prioritizing customer requirements in QFD: an industrialized housing application. IIE Transactions. 1994;26:72-9.

[66] Zhang H, Ouzrout Y, Bouras A, Della Selva V, Savino MM. Selection of product lifecycle management components based on AHP methodologies. International Conference on Advanced Logistics and Transport. 2013;523-8.

[67] Abdullah T WD, Lashlem A. An overview use of analytic hierarchy process (AHP) in design for remanufacturing activities. Proceedings of the International Symposium on the Analytic Hierarchy Process. 2013:1-14.

[68] Pigosso DC, Zanette ET, Guelere Filho A, Ometto AR, Rozenfeld H. Ecodesign methods focused on remanufacturing. Journal of Cleaner Production. 2010;18:2131.

[69] Knop V, Loos M, Pera C, Jeuland N. A linear-by-mole blending rule for octane numbers of n-heptane/iso-octane/toluene mixtures. Fuel. 2014;115:666-73.

[70] Abu M, Jamaluddin K, Zakaria M. Classification of crankshaft remanufacturing using Mahalanobis-Taguchi system. International Journal of Automotive and Mechanical Engineering. 2016;13(2): 3413-22.

[71] Sundin E. Product and process design for successful remanufacturing: Linköping University Electronic Press; 2004. 